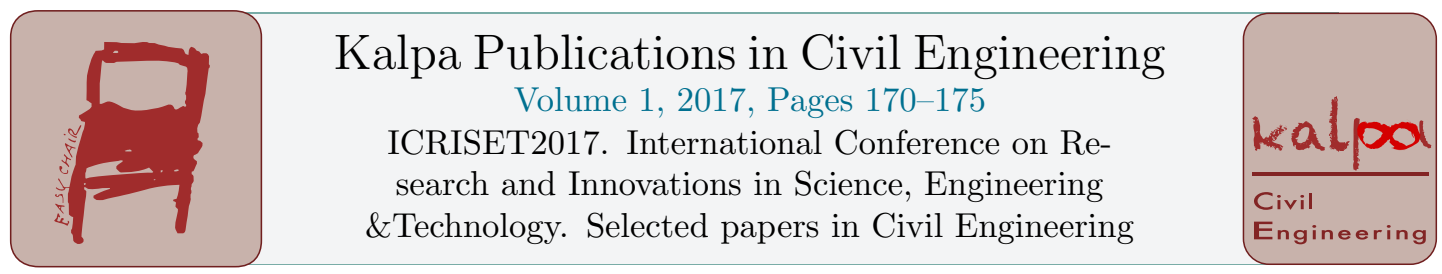

\title{
The Utilization of Quarry Dust as Fine Aggregates in Concrete
}

\author{
Vishal Agrawal ${ }^{1}$, Pankil Shah ${ }^{1}$, Armaan Gupta ${ }^{1}$ and Rahul Shah ${ }^{2}$ \\ ${ }^{1}$ Under graduate Student, Civil Engineering Department \\ School of Engineering and Technology, Navrachana University \\ Vadodara, India \\ ${ }^{2}$ Assistant Professor, Civil Engineering Department \\ School of Engineering and Technology, Navrachana University \\ Vadodara, India \\ agrawalvishal164@gmail.com , pankil.shah555@gmail.com , armaangupta159@gmail.com , \\ rahuls@nuv.ac,in
}

\begin{abstract}
In the view of the expeditious growth of infrastructure around the globe, there is an acute shortage of building materials and also a very stern problem of the disposal of the remaining and continuously generating waste. The demand of natural sand in the construction industry also has magnificently increased resulting in the rapid depletion of the river beds which are the natural sources of sand. Acute shortage of good quality of sand has resulted in to considerable increase in its price ultimately affecting the construction cost. Thus there is a severe need to identify a suitable substitute of sand which is eco-friendly and can be used effectively in construction practices mainly in concrete which requires sand as fine aggregates. An attempt is required to investigate use of some alternative materials to save precious natural resources. The current study focuses on determining suitability of using quarry dust, which is a waste product from quarry, as fine aggregates in traditional concrete. During the tenure of the study, some physical and engineering properties of quarry dust and sand were determined and compared. The compressive strength of concrete was determined after replacing sand with quarry dust in various ratios. The results of the study showed encouraging results for replacement of $50 \%$ of sand with quarry dust.
\end{abstract}

\section{Introduction}

The world around us is rapidly evolving and so is the world infrastructure. The infrastructure industry has witnessed a rapid and enormous growth in last decade. This decade has proven to be a golden era for the infrastructure industry \& the construction community. But with this rapid growth, the resources were also rapidly utilized. Consequentially today, the infrastructure industry is facing a serious problem of shortage of

C.D. Modhera, G.J. Joshi, D. Soni, I.N. Patel, A.K. Verma, L.B. Zala, S.D. Dhiman, D.R. Bhatt, J.M. Rathod, B.C. Goradiya, M.S. Holia and D.K. Patel (eds.), ICRISET2017 (Kalpa Publications in Civil Engineering, vol. 1), pp. 170-175 
construction materials due to the rapid depletion of the resources. Thus as civil engineers it is our role towards the industry to contribute in the eco friendly and green construction and development. Our main focus as engineers should be towards maintaining the balance between construction and sustainable environment. One of the way to achieve that can be using of alternative material and material sources.

Today, Concrete is the most widely used composite construction material. The major constituents of concrete are coarse aggregate, fine aggregate, cement and water. The function of the fine aggregate is to assist in producing workability and uniformity in the mixture. It is conventional that Sand is being used as fine aggregate in concrete. The major source of sand is river beds which have been extensively used and depleted. This depletion and thus shortage of sand has caused a noticeable increase in the price of sand. Hence we are forced to think of alternative materials.

Quarry dust is by product from the extraction of aggregates. The aggregates are extracted from quarries by using various methods. But after the extraction of aggregates, there are remains of the rocks in the form of fine dust. About $20-25 \%$ of the total material crushed in a crusher unit for extraction of aggregates is left as fine dust and is considered to be waste. This fine dust is generally known as quarry dust. Quarry dust has particle size distribution close to that of sand. It is also found that utilization of quarry dust as fine aggregates in concrete provides sufficient workability and also the required strength. Utilization of quarry dust will conveniently decrease the demand of natural sand hence help in reducing the rate of depletion of resources and also provide some time for the resources to be replenished. Utilization of quarry dust not only relieves the pressure on sand but also reduces the need for dumping of quarry dust which was considered waste product in the quarries. This can prove to be an effective alternative for replacement of sand if found convenient.

The major objectives of the study were as follows:-

1. To determine the significant properties of quarry dust and compare it with the properties of conventional sand.

2. To determine the best suitable ratio of Sand: Quarry Dust in concrete to obtain the desired design compressive strength.

\section{Literature Review}

I. G. Balamurugan and Dr. P. Perumals carried out an experimental study on the replacement of sand with quarry dust in the conventional concrete. In the tenure of the study, they experimentally determined the properties of sand and quarry dust. These properties were then compared and tabulated in the study. They also experimentally determined the compressive strength of normal concrete and compared it with the results of compressive strength of concrete at high temperature and under thermo shock. It was concluded that the partial replacement of sand with quarry dust in the 50\% - 50\% (Mix 3) ratio was the most effective and showed an increase in compressive strength. It was also concluded that the compressive strength of concrete, with $50 \%$ Sand and $50 \%$ quarry dust (Mix 3), under thermo shock and high temperature showed the least reduction in strength. It was finally concluded that quarry dust can be effectively used for $50 \%$ replacement of sand in the conventional concrete. 
II. Chandana Sukesh, Katakam Bala Krishna, P.Sri Lakshmi Sai Teja and S.Kanakambara Rao have conducted an experimental study on the feasibility and suitability of the use of quarry dust for the partial replacement of sand in concrete. In the tenure of the study, the authors determined some important parametric properties of quarry dust. Also cubes for the partially replaced concrete of size $150 \mathrm{~mm} \times 150 \mathrm{~mm}$ were casted, cured and then tested for the compressive strength. In this study the properties of concrete, consisting of sand partially replaced with quarry dust, like water absorption, specific gravity, workability etc. were determined. The study concluded that the replacement of sand with quarry dust led to an increase in the compressive strength of concrete samples. It was also concluded that the workability of the concrete mix decreases with the increase in percentage of quarry dust. Also the specific gravity of both the materials i.e. sand and quarry dust were found to be almost same. It was suggested that the ideal percentage of replacement of sand with quarry dust can be between $55-75 \%$. It was also suggested that $100 \%$ sand can also be replaced with quarry dust in presence and usage of fly ash.

III. H. S. Sureshchandra, G. Sarangapani, and B. G. Naresh Kumar also conducted an extensive experimental study on the effect of replacement of Sand by Quarry dust in Hollow concrete blocks. During the tenure of the study the authors investigated different properties of quarry which play an important role in the mix design of concrete. Then different mix proportions for different percentage of quarry dust $(50 \%$ and $100 \%)$ were tested under different water cement ratios also. The study was concluded as, the production of Hollow concrete blocks sand can be replaced partially (i.e. 50\% replacement).by quarry dust instead of complete replacement. The block where $50 \%$ replacement is adopted performs better than blocks which are prepared conventionally using natural sand. Further admixtures can be used in the production of blocks for better performance. Hollow concrete blocks can be used in load bearing masonry structures.

\section{Methodology}

As emphasized earlier, natural sand needs to be effectively replaced by some alternative green material in order to maintain the balance in nature and consequently keep the environment sustainable for all living beings on the planet. Quarry dust is an upcoming alternative for the replacement of sand. Quarry dust according to the global research can effectively replace $50-60 \%$ of sand in conventional concrete. Thus the entire purpose of the study was to experimentally determine the feasibility of use of quarry dust in replacement of sand in conventional concrete.

During the tenure of the study, the study material i.e. quarry dust was collected from a quarry near Pavagadh, Halol. Quarry dust, being the test material and the most important basis of the entire research, was tested for some physical properties. Non Destructive Rebound Hammer test was performed at the interval of 7,21 and 28 days to obtain the compressive strength of concrete. 


\section{Material Properties and Mix Design}

\section{A. Material Properties}

The materials used for casting of cube specimens were OPC cement of 53 grade, sand and quarry dust passing through is $4.75 \mathrm{~mm}$ sieve having the following properties:

Table I Physical Properties

\begin{tabular}{|r|c|r|c|}
\hline $\begin{array}{r}\text { Sr. } \\
\text { No. }\end{array}$ & Test & $\begin{array}{r}\text { S } \\
\text { and }\end{array}$ & $\begin{array}{c}\text { Quarry } \\
\text { Dust }\end{array}$ \\
\hline 1. & $\begin{array}{c}\text { Specific } \\
\text { Gravity }\end{array}$ & $\begin{array}{r}2 . \\
634\end{array}$ & 2.755 \\
\hline 2. & $\begin{array}{c}\text { Water } \\
\text { Absorption }\end{array}$ & $\begin{array}{r}0 . \\
72\end{array}$ & 3.59 \\
\hline
\end{tabular}

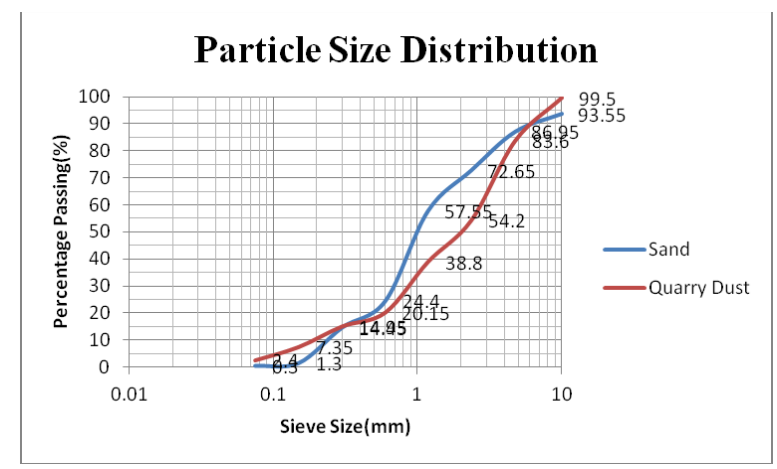

Figure 1 Particle Size Distribution

\section{B. Mix Design}

Mix design was carried out using IS:10262-(2009). The physical properties obtained from the tests performed on the quarry dust and sand were incorporated in the mix design for concrete. The concrete mix design was done to obtain the design strength of 30MPa. The mix design was done as per the IS 10262- 2009: Guidelines for Concrete Mix Design. The ratio of cement: fine aggregates: coarse aggregates, was obtained as 1: 1.35: 2.48 for water cement ratio of 0.5 . 


\section{Casting of Cube Specimens}

Mix The concrete mix according to the mix design was prepared without the use of any admixtures. Concrete cubes of $150 \mathrm{~mm} \times 150 \mathrm{~mm} \times 150 \mathrm{~mm}$ were casted with different ratios of sand to quarry dust. Sand was replaced by quarry dust in the proportions of $25 \%, 50 \%$, $75 \%$ \& $100 \%$ in concrete \& cubes were casted using this concrete containing quarry dust. The compressive strength of these cubes were tested after 7 days, 21 days \& 28 days \& the results thus obtained were compared to the compressive strength of the cubes made up of conventional concrete containing no quarry dust.

\section{Results and Discussions}

\section{A. Compressive Strength}

The cubical specimens were tested for compressive strength at the end of 7,21 and 28 days using a rebound hammer. The compressive strength of the concrete is tabulated below:

Table II Average Compressive Strength of Concrete

\begin{tabular}{|c|c|c|c|c|}
\hline Sr No. & Ratio & \multicolumn{3}{|c|}{ Compressive Strength (MPa) } \\
\hline & & $\begin{array}{r}7 \\
\text { Days }\end{array}$ & $\begin{array}{r}21 \\
\text { Days }\end{array}$ & $\begin{array}{c}28 \\
\text { Days }\end{array}$ \\
\hline 1 & $\mathrm{M}-0$ & 22.25 & 28.55 & 34.95 \\
\hline 2 & $\mathrm{M}-25$ & 18.45 & 23.7 & 31.32 \\
\hline 3 & $\mathrm{M}-50$ & 21.3 & 26.8 & 32.55 \\
\hline 4 & $\mathrm{M}-75$ & 19.75 & 23.38 & 30.22 \\
\hline 5 & $\mathrm{M}-100$ & 18.9 & 23.5 & 28.75 \\
\hline
\end{tabular}

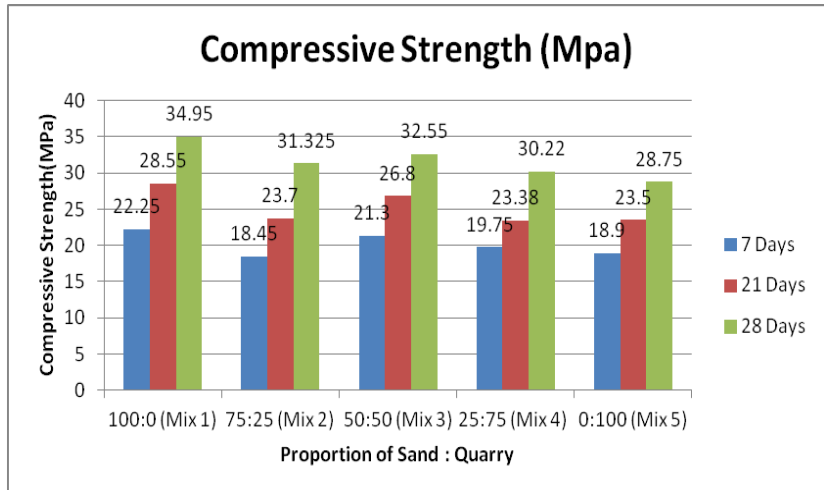

Figure 2 Average Compressive Strength of Concrete. 
From figure 2 , it can be concluded that the compressive strength of the concrete mix increases upto the replacement of $50 \%$ of sand with quarry dust. After that the compressive strength of the mix show a tendency to decrease.

\section{Conclusion}

The study was an experimental attempt to determine the feasibility of replacement of sand with quarry dust as fine aggregates in conventional concrete. The entire data collected during the tenure of the study can be summed up as follows:-

1. Sand obtained from the river beds and the quarry dust obtained from the quarries has almost equal specific gravity but have a large variation in the water absorption. The water absorption of quarry dust which was determined as 3.59\% was very high due to which the concrete mix prepared with higher proportion of quarry dust has very low workability.

2. Quarry dust as a material is very much similar to sand in physical properties and is very cheaply available as it is a waste by product from the extraction of aggregates. Cost of quarry dust is almost $10 \%$ of the cost of natural sand.

3. The compressive strength of the concrete tends to decrease by the use of quarry dust which is witnessed from the results of the various experiments conducted. The maximum compressive strength was obtained by replacing $50 \%$ (Mix 3 ) of sand with quarry dust but it was less than the strength shown by the conventional concrete (100\% (Mix 1) sand as fine aggregates).

4. But as the cost of quarry dust is very less in comparison to the current cost of sand due to its shortage, quarry dust can be seen as an effective and optimistic alternative for the replacement of sand in concrete.

\section{Reference}

i. Chandana Sukesh, K. B. (May 2013). Partial Replacement of Sand with Quarry Dust in Concrete. International Journal of Innovative Technology and Exploring Engineering .

ii. H. S. Sureshchandra, G. S. (February 2014). Experimental Investigation on the Effect of Replacement of Sand by Quarry Dust in Hollow Concrete Block for Different Mix Proportions. International Journal of Environmental Science and Development .

iii. India, G. o. (n.d.). Indian Standard 10262- 2009: Guidelines for Concrete Mix Design. India: Government of India.

iv. India, G. o. (n.d.). Indian Standard 2386- Part 1: Methods of test for aggregates for concrete. India: Government of India.

v. India, G. o. (n.d.). Indian Standard 2386- Part 3: Methods of test for aggregates for concrete. India: Government of India.

vi. India, G. o. (n.d.). Indian Standard 2386- Part 4: Methods of test for aggregates for concrete. India: Government of India.

vii. $\quad$ Perumals, G. B. (December 2013). Use of Quarry Dust to Replace Sand in Concrete - An Experimental Study. International Journal of Scientific and Research Publications , 3 (12). 